\title{
Assessing Generic Competence Development among Higher Education Students
}

\author{
Ashfaque Ahmad Shah* \\ Muhammad Sarwar \\ Shafqat Ali Shah ${ }^{* * *}$
}

\begin{abstract}
Present study intended to assess the generic competences of higher education students. Self-perceived level of generic competences of the students in the beginning and the end of an academic session was recorded to explore the role of higher education in imparting them the generic competences. All the students entering the University of Sargodha (Pakistan) during 2012, constituted the population of the study. Cluster sampling technique was used to carry out the panel survey. The same cohort of the students was surveyed twice over a period of one academic year. This study adopted a version of the Reflex Project instrument, consisting of 19 competences, to collect data from students of both genders in public-sector universities in Pakistan. Data were collected from 932 students (cluster sampling) studying at 10 (randomly) selected departments. There were 408 male and 525 female students in the study. The students rated themselves on a seven-point scale whose reliability was 0.82 . The results indicated that higher education played its role in imparting and promoting the existing set of generic competences from the beginning to the end of the academic session; but the increase in the competence level was noted only to a modest level. Gender differences were found among the students in a few of the generic competences.
\end{abstract}

Keywords: Generic competence, higher education, gender differences.

\footnotetext{
* Assistant Professor, Department of Education, University of Sargodha, Pakistan, Email: multanxa@gmail.com

${ }_{* *}^{*}$ Professor, Department of Education, University of Sargodha, Pakistan,

Email: drsarwar@ymail.com

**** Assistant Professor, Department of Education, University of Gujrat, Pakistan, Email: drsas63@gmail.com
} 


\section{Introduction}

The quality of higher education improves a country's ability to supply highly qualified workers to the job market (Hernández, March et al., 2009). The job market demands both specific and generic competences from prospective employees (Mason et al., 2009). Crucially, higher education is considered to be the key link between education and employment (Shah, 2009). Competence-based education in particular is expected to provide a gradual transition from education to workplace (Fastré et al., 2013). In "competence-based education" the objectives and the curricula are determined using competences as a foundation (Kamphorst et al. 2012; Teichler, 1999). This study focuses on higher education's role to impart generic competences, with our study highlighting gender differences in Pakistan. Higher education is expected to develop three types of competences: discipline-specific competence, generic competence and disposition competence (Chan et al. 2013; Shah, 2009).

Pakistan is world's $9^{\text {th }}$ most populous country. A student can enter into higher education in Pakistan, after successfully completing their 12 years of schooling. Higher education institutions are universities, (affiliated) colleges and degree-awarding institutes (DAIs). Institutions of higher education are autonomous organisations. Respective provincial governments and the Higher Education Commission of Pakistan are chiefly responsible for their finances.

Government of Pakistan defined her target of increasing present higher education enrolment from $3.7 \%$ (in 2009) to $15 \%$ by 2020 , in the National Education Policy (2009). There is governmental recognition of the importance of social sciences for developing civic and cultural values, and for conflict resolution. Institutions of higher education in Pakistan are struggling to train faculty, build educational capacity, increase enrolment and raise the quality of research (Fair, 2007; Haider, 2008; Khalid and Khan, 2006; Memon, 2007; Shami and Hussain, 2006).

Objective of the study was to analyse the levels of students' generic competences at the time of entering and leaving the institution of higher education. Gender differences of the students of higher education in Pakistan have also been studied. 


\section{Literature Review}

Knowledge, skills and attitudes get combined to make a monolithic whole i.e. competence, in order to function in a particular scenario (Baartman and Ruijs, 2011). Competence is a formally documented individuals' capability making them able to work in an occupation (Pukelis, 2009; Pukelis and Pileicikiene, 2009). Competence covers three main elements; namely, "an adequate knowledge base", secondly, "the professional performance of complex tasks", and thirdly, "the capacity for life-long learning" (Baartman et al. 2013; Van der Vleuten et al. 2010). Graduates of higher education gain generic and specific competences, and both are important for employment (Clanchy and Ballard, 1995; Gonczi, 2003). Specific competences help individuals perform a very specific function, and these are known as 'hard skills' (Ashworth and Saxton, 1990). Generic competences help individuals get integrated in the changing world of work (Collis and Montgomery, 1995).

Universities are responsible for the assessment of the students learning outcomes (Hughes, 2013), which do include competences. Competence can be objectively assessed by an outside observer (Epstein and Hundert, 2002); but it needs high investment of time and resources, and it requires complex data herein (Van Der Vleuten, 1996). In another approach, the individual subjects rate themselves (Gonczi, 1994; McNamara, 2013). This self-assessment method is easier to implement although a few scholars have questioned its reliability (Norman et al. 2002). According to Shah (2009) self-assessment is a befitting method for generic competences. It is economic, easy way and the direct source of information, especially at higher education level (Shah, 2009).

Both specific and generic competence are required in the job market (Pukelis and Pileicikiene, 2009; Shah, 2009). While there is some criticism in academic quarters that higher education may be downgraded to job training programmes (Harvey, 2000).

Higher education is to prepare individuals for the world of work (Nunan, 1999) and the interest in generic competences at higher education level has increased greatly (García-Aracil and Van der Velden, 2008; Teichler, 1999). With high focus at policy level, this interest in competence is unobserved in practice. It is direly lacking in the curriculum as well as in the assessment practices (Fallows and Steven, 2000), at least in Pakistan. Despite being claimed to be implicit (Singh et al., 2012) the generic competences are now progressively recognised to be explicit in the curriculum (Maher and Graves, 2007; Pandiyan, 2011; 
Yorke et al., 2004). The debate on their implicit/explicit inclusion in the curriculum is going on (King, 2011).

Teaching of generic competence has not been marked in Pakistani higher education institutes (Haider, 2008). If the growth of generic competence is high on the agenda of higher education, then its assessment should also be high. We know that Pakistani higher education is assessment oriented (Ali et al., 2009). Therefore, the assessment of generic competence, if put high in the assessment practices, will help developing it among the graduates. It is observed that during only one academic session the assessment practices greatly improved the level of generic competences (Dainty et al., 2004; Fortin and Legault, 2010; Male et al., 2011). Better acquired level of generic competence during higher education guarantees better professional performance (Schaeper 2009; Williams, 2003).

We aim at to evaluate the contribution of higher education in developing generic competences among students of higher education in Pakistan. It is expected that this study will be an evidence for students, teachers, administrators and policy makers.

\section{Methodology}

This section deals with the methods and procedures of this study.

\section{Design of the Study}

This is a descriptive study. Descriptive research explains situations, evaluates data and draws conclusions for synthesising ideas (Saunders et al. 2011). High volume of data is collected in survey research, and the findings are considered demonstrative of the population (Bordens, 2006; Robson, 2002). Longitudinal and cross sectional surveys are the common types of it (Gay et al., 2006; Kothari, 2004). For this study a longitudinal survey was taken on. Longitudinal survey demands for data collection at two or more times (Shami and Hussain, 2006), and the longitudinal survey can be categorised into four types: cohort survey, follow-up survey, panel survey, and trend survey (Gay et al., 2006). A panel survey was selected for this study because it involves a sample in which the same cohort of individuals are tracked over a period of time (Yee and Niemeier, 1996). 


\section{Population and Sample}

All entrants who were enrolled in 2012 in all departments of the University of Sargodha, Pakistan constituted the population of the study. The University of Sargodha, established in 2002 and now with 18,000 students, is situated in central Punjab and mainly serves local students. There are seven faculties and 34 departments in the university, out of which 10 were randomly selected.

The sampling and data collection was done by giving due consideration to the following: "sampling error, non-coverage error, measurement error, and non-response error" (Dillman, 1991; Fagarasanu and Kumar, 2002). To respond to sampling error and non-coverage, a cluster sampling technique was used. This technique of sampling is also known as probability sampling or chance sampling (Kothari, 2004) in which each individual has an equal probability of being selected (or not selected) in the sample.

The names of all the 34 academic departments were written on paper slips. These paper slips were folded and mixed in a small box. One of the fellow faculty members was asked to pick up any 10 paper slips. These departments were: Agriculture, Commerce, Education, English, Mathematics, Pharmacy, Physics, Psychology, Sociology and Zoology. As a result, 932 students of University of Sargodha from these 10 departments were selected for data collection: 179 students from Agriculture, 44 from Commerce, 250 from Education, 76 from English, 51 from Mathematics, 20 from Pharmacy, 59 from Physics, 192 from Psychology, 23 from Sociology, and 38 from Zoology. There were 408 male and 525 female students in the study.

\section{Instrument of the Study}

The instrument used in this study was the generic competence scale consisting of 19 competences developed by the Reflex Project (RP) in western context and used by Shah (2009) in the Pakistani context. This scale employs seven responses against each statement (very low as 1 , low as 2 , slightly below average as 3 , average as 4 , slightly above average as 5 , high as 6 , and very high as 7 ).

The scale was duly validated to minimise measurement error, and personal visits reduced the level of non-responses. The instrument was tested on 57 students as a random sample. Cronbach's Alpha value was 0.82 , showing high reliability of the research instrument. 
Data were collected from 10 departments of University of Sargodha. Data were collected in two phases. In the first phase, data were collected at the time of admission into the university. The students were briefed about the nature of the study and were formally requested to consent to the confidential study and rate themselves on a list of 19 generic competences against a seven point scale. After verbal permission from the students a written consent was obtained from every student participating in the study. The data for phase one was obtained after one week of the admission. The same procedure was adopted for data collection in the second phase. About $10 \%$ of students had left due to different reasons, and those students were dropped from the study.

\section{Results}

Data were collected against a seven point scale. The seven point scale may be taken as an interval or an ordinal scale in this study, as interval data also possesses qualities of ordinal data (Fagarasanu and Kumar, 2002). As data of the study were ordinal as well, so the median was used as a measure of central tendency (Wilcox and Keselman, 2003). The percentage of responses was calculated per item to reveal which level was preferred by the respondents against each competence. A nonparametric Wilcoxon signed-rank test was used to ascertain the difference between level of competences at the beginning and end of the academic session. This nonparametric test is a frequently used for paired data (Ghaemi et al., 2000). Independent sample tests (Mann and Whitney, 1947) were applied to variables regarding gender to discover any difference in responses at the beginning and end of the academic session. To this end, the variables were analysed by using $\mathrm{K}$ Independent sample tests. This study employed the Mann-Whitney U test to check for differences between generic competences at the start and at the end of academic session. The Mann-Whitney $U$ test is often considered as a nonparametric equivalent t-test (McKnight and Najab, 2010). 
Table 1

Generic competences in the beginning and end of academic session

\begin{tabular}{lccc}
\hline Competences & $\begin{array}{c}\text { Median } \\
\text { (at the } \\
\text { end) }\end{array}$ & $\begin{array}{c}\text { Median } \\
\text { (at the } \\
\text { start) }\end{array}$ & $\begin{array}{c}\text { Median } \\
\text { Difference }\end{array}$ \\
\hline 1. Subject Mastery & 4 & 3 & 1 \\
2. General Knowledge & 4 & 3 & 1 \\
3. Analytical Thinking & 4 & 3 & 1 \\
4. Acquiring knowledge & 5 & 3 & 2 \\
5. Effective negotiation & 5 & 3 & 2 \\
6. Working under pressure & 4 & 3 & 1 \\
7. Alertness (to new opportunities) & 5 & 3 & 2 \\
8. Coordination activities & 5 & 4 & 1 \\
9. Effective use of time & 5 & 3 & 2 \\
10. Work Productively (with others) & 5 & 4 & 1 \\
11. Mobilize others & 5 & 3 & 2 \\
12. Effective Communication & 5 & 3 & 2 \\
13. Assertiveness & 5 & 3 & 2 \\
14. Computer and internet & 5 & 4 & 1 \\
15. New ideas & 5 & 3 & 2 \\
16. Question ideas & 5 & 3 & 2 \\
17. Presentation & 4 & 3 & 1 \\
18. Writing (reports, memos or & 4 & 3 & 1 \\
19. Focuments) & 4 & 3 & 1 \\
\hline
\end{tabular}

At end of the academic session (as Table 1 shows) 7 competences exhibited the median of 4 on the scale (1-7), specifically in subject mastery, knowledge of other fields, analytical thinking, performance under pressure, presentation skills, office drafting, and communication in foreign language. The respondents rated themselves at median 5 'slightly above average' in 12 out of 19 competences. These competences were the acquisition of new knowledge, effective negotiation, utilization of new opportunities, time utilization, mobilization of others' capacities, effective communication, asserting authority, innovation, questioning one's own and others' ideas, activity coordination, productive working with others, and computer skills.

Results of (paired sample) t-test are shown in the Table 2. The P value for all the competences is .000 which shows significant difference between levels of competences of two measurements. This result illustrates that higher education may have played role in imparting generic competences among students. 
Table 2

Mean Scores of Acquired Competences

\begin{tabular}{llllll}
\hline Competences & $\begin{array}{l}\text { Mean } \\
\text { (at End) }\end{array}$ & $\begin{array}{l}\text { Mean } \\
\text { (at Start) }\end{array}$ & Difference & t- score & P \\
\hline Subject Mastery & 4.30 & 3.14 & 1.16 & $28.679 *$ & .000 \\
General Knowledge & 4.18 & 3.48 & 0.70 & $18.420^{*}$ & .000 \\
Analytical Thinking & 4.31 & 3.31 & 1.00 & $25.975^{*}$ & .000 \\
Acquiring knowledge & 4.79 & 3.44 & 1.35 & $32.725^{*}$ & .000 \\
Effective negotiation & 4.46 & 3.41 & 1.05 & $27.218^{*}$ & .000 \\
Working under pressure & 4.32 & 3.29 & 1.04 & $26.731^{*}$ & .000 \\
Alertness (to new & 4.57 & 3.24 & 1.33 & $31.374 *$ & .000 \\
opportunities) & 4.67 & 3.48 & 1.19 & $27.617 *$ & .000 \\
Coordination activities & 4.78 & 3.31 & 1.47 & $32.628^{*}$ & .000 \\
Effective use of time & 4.78 & & & & \\
Work Productively (with & 4.58 & 3.51 & 1.07 & $26.981 *$ & .000 \\
others) & 4.57 & 3.28 & 1.29 & $32.557 *$ & .000 \\
Mobilize others & & & & & \\
Effective & 4.81 & 3.27 & 1.54 & $36.081 *$ & .000 \\
Communication & 4.67 & 3.24 & 1.43 & $34.285^{*}$ & .000 \\
Assertiveness & 4.71 & 3.93 & 0.78 & $21.568 *$ & .000 \\
Computer and internet & 4.63 & 3.35 & 1.28 & $30.127 *$ & .000 \\
New ideas & 4.67 & 3.24 & 1.42 & $33.331^{*}$ & .000 \\
Question ideas & 4.40 & 3.19 & 1.21 & $28.073 *$ & .000 \\
Presentation & & & & & \\
Writing (reports, memos & 4.41 & 3.25 & 1.16 & $28.680^{*}$ & .000 \\
or documents) & 3.88 & 3.18 & 0.70 & $20.162^{*}$ & .000 \\
Foreign language & & & & & \\
\hline
\end{tabular}

Table 3 shows that male students reported more "mastery of their own field or discipline" across the study. At the beginning of the academic session, there was no reported significant gender difference $(\mathrm{U}=10549.2$, $\mathrm{p}=.718$ ) in the competence, but this difference became significant $(\mathrm{U}=97902.5, \mathrm{p}=.018)$ by the end of the programme in favour of male students. The greatest anomaly was found in "Knowledge of other fields or discipline". At the beginning of the session the male students rated themselves significantly better $(\mathrm{U}=94377.5, \mathrm{p}=.002)$ than female students, but by the end of the programme the female students rated themselves significantly better $(\mathrm{U}=97562.0, \mathrm{p}=.016)$ than the male ones. After admission to university, the female students were exposed to co-education and the academic disciplines. This might be reason of the higher rating of female students than male students at the end of the academic programme. There was significant difference $(\mathrm{U}=98474.0, \mathrm{p}=.035)$ in the 'ability to negotiate effectively' at the start of the session favouring male students, but at the end of the session there was no significant difference ( $U=101679.0$, $\mathrm{p}=.173$ ) between female and male students. 
Table 3

Gender Differences of Acquired Competences

\begin{tabular}{|c|c|c|c|c|c|c|c|}
\hline \multirow[b]{2}{*}{ Competences } & \multirow[b]{2}{*}{$\begin{array}{l}\text { Gender } \\
(n)\end{array}$} & \multicolumn{3}{|c|}{ start of academic session } & \multicolumn{3}{|c|}{ end of academic session } \\
\hline & & $\begin{array}{l}\text { Mean } \\
\text { Rank }\end{array}$ & $\begin{array}{l}\text { Mann } \\
\text { Whitney } \\
\text { U }\end{array}$ & $\mathrm{P}$ & $\begin{array}{l}\text { Mean } \\
\text { Rank }\end{array}$ & $\begin{array}{l}\text { Mann } \\
\text { Whitney } \\
\text { U }\end{array}$ & $P$ \\
\hline \multirow{2}{*}{ 1. Subject Mastery } & Male (408) & 463.06 & \multirow{2}{*}{105492.0} & \multirow{2}{*}{.718} & 444.46 & \multirow{2}{*}{97902.5} & \multirow{2}{*}{.018} \\
\hline & Female (524) & 469.18 & & & 483.66 & & \\
\hline \multirow[t]{2}{*}{ 2. General Knowledge } & Male (408) & 435.82 & \multirow[t]{2}{*}{94377.5} & \multirow[t]{2}{*}{.002} & 489.38 & \multirow[t]{2}{*}{97562.0} & \multirow[t]{2}{*}{.016} \\
\hline & Female (524) & 489.55 & & & 448.69 & & \\
\hline \multirow[t]{2}{*}{ 3. Analytical Thinking } & Male (408) & 465.8 & \multirow[t]{2}{*}{106612.0} & \multirow[t]{2}{*}{.941} & 455.84 & \multirow[t]{2}{*}{102548.5} & \multirow[t]{2}{*}{.257} \\
\hline & Female (524) & 467.04 & & & 474.80 & & \\
\hline \multirow[t]{2}{*}{ 4. Acquiring knowledge } & Male (408) & 452.69 & \multirow[t]{2}{*}{101260.5} & \multirow[t]{2}{*}{.145} & 448.58 & \multirow[t]{2}{*}{99585.0} & \multirow[t]{2}{*}{.059} \\
\hline & Female (524) & 477.25 & & & 480.45 & & \\
\hline \multirow[t]{2}{*}{ 5. Effective negotiation } & Male (408) & 446.53 & \multirow[t]{2}{*}{98747.0} & \multirow[t]{2}{*}{.035} & 453.71 & \multirow[t]{2}{*}{101679.0} & .173 \\
\hline & Female (524) & 482.05 & & & 476.46 & & \\
\hline 6. Working under pressure & Male (408) & 483.42 & 99994.0 & .076 & 486.39 & 98779.5 & .039 \\
\hline & Female (524) & 453.33 & & & 451.01 & & \\
\hline 7. Alertness & Male (408) & 481.05 & 100961.0 & .127 & 453.13 & 101439.0 & .158 \\
\hline & Female (524) & 455.17 & & & 476.91 & & \\
\hline 8. Coordination activities & Male (408) & 467.37 & 106540.5 & .928 & 462.28 & 105175.0 & .659 \\
\hline & Female (524) & 465.82 & & & 469.78 & & \\
\hline 9. Effective use of time & Male (408) & 452.56 & 101209.0 & .142 & 444.09 & 97751.0 & .019 \\
\hline & Female (524) & 477.35 & & & 483.95 & & \\
\hline 10. Work Productivity & Male (408) & 470.2 & 105387.0 & .696 & 457.37 & 103172.5 & .335 \\
\hline & Female (524) & 463.62 & & & 473.62 & & \\
\hline 11.Mobilize others & Male (408) & 462.46 & 105247.0 & .667 & 450.03 & 100176.0 & .082 \\
\hline & Female (524) & 469.65 & & & 479.32 & & \\
\hline 12.Effective Communication & Male (408) & 454.9 & 102161.5 & .217 & 458.21 & 103513.5 & .385 \\
\hline & Female (524) & 475.54 & & & 472.96 & & \\
\hline 13. Assertiveness & Male (408) & 476.8 & 102695.5 & .274 & 459.20 & 103917.5 & .445 \\
\hline & Female (524) & 458.48 & & & 472.18 & & \\
\hline 14. Computer and internet & Male (408) & 494.68 & 95398.5 & .003 & 437.63 & 95115.5 & .003 \\
\hline & Female (524) & 444.56 & & & 488.98 & & \\
\hline 15. New ideas & Male (408) & 437.62 & 95112.5 & .002 & 443.82 & 97643.5 & .017 \\
\hline & Female (524) & 488.99 & & & 484.16 & & \\
\hline 16.Question ideas & Male (408) & 461.96 & 105045.5 & .632 & 423.21 & 89234.5 & .000 \\
\hline & Female (524) & 470.03 & & & 500.21 & & \\
\hline
\end{tabular}




\begin{tabular}{llllllll} 
17.Presentation & Male (408) & 473.71 & 103954.5 & .446 & 450.74 & 100467.0 & .103 \\
& Female (524) & 460.89 & & & 478.77 & & \\
18.Writing & Male (408) & 480.43 & 101213.0 & .140 & 469.47 & 105685.0 & .757 \\
& Female (524) & 455.65 & & & 464.19 & & \\
19.Foreign language & Male (408) & 474.27 & 103726.5 & .416 & 488.89 & 97762.5 & .018 \\
& Female (524) & 460.45 & & & 449.07 & & \\
\hline
\end{tabular}

One reason for the gender differences in this study might be found in the social and cultural situation of Pakistan. There is significant difference in the culture outside the university and the culture inside the campus. The male students have more experience regarding negotiating in different situations of life, while female students have limited exposure to negotiating, as social norms in Pakistan do not encourage free communications between men and women. However, in the university setting, male and female students do talk and discuss in the form of groups in their free time. This exposure gives more chance to female students to improve their negotiation skills. A similar trend is seen in the "ability to perform well under pressure". There was no significant difference $(\mathrm{U}=99994.0, \mathrm{p}=.076)$ in the competence at the start of the programme, but this difference became significant $(\mathrm{U}=$ 98779.5, $\mathrm{p}=.039$ ) at the end of the programme, favouring female students. Male and female students were similar $(\mathrm{U}=101209.0, \mathrm{p}=.142)$ in their 'ability to use time efficiently' at the start of the session but at the end of the session males were self-reporting significantly better ( $\mathrm{U}=$ 97751.0, $\mathrm{p}=.019)$ than their female counterparts.

The "ability to use the computer and the Internet" showed irregular behaviour from a gender perspective. At the start of the session female students rated themselves significantly better $(\mathrm{U}=95398.5, \mathrm{p}=.003)$ than their male counterparts. Quite interestingly, after the academic session males performed better $(\mathrm{U}=95115.5, \mathrm{p}=.003)$ than the female ones. The reason might be that in Pakistan most female students have a higher socio-economic status than their male counterparts. In Pakistan, computers and Internet facilities are more common among people who are comparatively wealthy. Hence, computer and Internet facilities were more accessible to female students at the time of admission, so they rated themselves higher at the start of programme. Over time, however, these gender differences diminish. The university has computer and Internet facilities, and all students in the university take a 3-credit compulsory course in computers. That might be one reason why male students rate themselves higher than female students. 
Male students rated themselves significantly higher than the female students at the start $(\mathrm{U}=95112.5, \mathrm{p}=.002)$ and end $(\mathrm{U}=97643.5, \mathrm{p}=.017)$ of the academic session in the "ability to come up with new ideas and solutions". Regarding the "willingness to question your own and others' ideas", no difference was found at the start of the session, but at the end of the session male students rated themselves significantly higher ( $U=$ 89234.5, $\mathrm{p}=.000$ ) than their female counterparts. Conversely, there was no difference in the "ability to write and speak in a foreign language" at the start of the session, but at the end of the session female students rated themselves significantly higher $(\mathrm{U}=97762.5, \mathrm{p}=.018)$ than their male counterparts.

Table 3 contains the results of Mann-Whitney statistics at the start of academic session. The $U$ test statistics showed that male and female students were not different on 14 out of 19 competences (see Table 3). Male and female students only showed differences in four competences. Female students assessed themselves higher than their male counterparts on one competence "ability to use computers and the Internet" $(\mathrm{U}=95112.5, \mathrm{p}=0.002)$. Male students assessed themselves higher than female students on following three competences "knowledge of other fields or disciplines" $(\mathrm{U}=94377.5, \mathrm{p}=0.002)$, "ability to negotiate effectively" ( $\mathrm{U}=98747.0, \mathrm{p}=0.035)$, and "ability to come up with new ideas and solutions" ( $\mathrm{U}=95112.5, \mathrm{p}=0.002)$.

The following are the results of the data set taken at the end of the academic session. The U-test statistics showed that male and female students displayed no differences on 11 out of 19 competences (see Table 2). Male and female students displayed differences in 8 competences. Female students assessed themselves higher than male students in three competences: "knowledge of other fields or disciplines" $(\mathrm{U}=97562.000, \mathrm{p}=0.016$, "ability to perform well under pressure" $(\mathrm{U}=98779.000, \mathrm{p}=0.039)$, and "ability to write and speak in foreign language" ( $U=97762.000, p=0.018)$. Male students assessed themselves higher than female students in the following four competences: "mastery of your own field or discipline" $(\mathrm{U}=97902.5, \mathrm{p}=0.018)$, "ability to use time efficiently" ( $\mathrm{U}=97751.0, \mathrm{p}=0.019)$, "ability to use computers and the Internet" ( $U=95115.000, p=0.003)$, "ability to come up with new ideas and solutions" ( $\mathrm{U}=97562.000, \mathrm{p}=0.016)$, "willingness to question your own and others" ideas "( $U=97643.000, p=0.017)$. 


\section{Conclusion}

Higher education is indispensably important for Pakistan; because the quality of higher education improves a country's ability to supply highly qualified workers to the job market (Hernández-March et al., 2009). Researchers have identified a robust link between higher education and employment (Shah, 2009). Therefore, the role of universities in preparing their graduates for a successful future life has become further critical. And universities are vehemently looking for appropriate modern practical approaches to train their graduates for their better productivity. Recently, competence-based education has been found useful in providing graduates a steady transition from education to workplace (Fastré et al., 2013). The job market demands both specific and generic competences from prospective employees (Mason et al., 2009). Graduates of higher education gain generic and specific competences which are important for employment (Clanchy and Ballard 1995; Gonczi, 2003).

Recently, higher education in Pakistan is focussed on the training of its faculty members, building up their academic capacity, increasing the student enrolment and trying to raise the quality of research (Fair, 2007; Haider, 2008; Khalid and Khan, 2006; Memon, 2007; Shami and Hussain, 2006). Competences are found to be imperative for individuals' integration into the continuously changing world of work (Collis and Montgomery, 1995). Therefore, Hughes (2013) says that the universities are apprehensive of assessing the graduates' learning outcomes.

The development of generic competences during one academic session at higher education is significant in that the students seem to overestimate their competences in the beginning of the session, and underestimate at the end (Baartman and Ruijs, 2011). The measured level of generic competences of the students, when analysed at the start of academic session, was average and below average; at the end of academic session the overall level was average and slightly above average, with significant increases in all competences. The competence that showed the maximum increase was the 'ability to make meanings clear to others', and in second place was the "ability to use time efficiently". The minimum increase was noted in the competence of the "ability to write and speak in a foreign language".

Male and female students of higher education displayed different patterns of development in their generic competences. The male students reported more improvement in "ability to use computer and Internet", and having started from lower level they achieved a higher level than 
female students. The male students comparatively achieved better level than female students in the following competences: "mastery of your own field or discipline", "ability to use time efficiently", "ability to come up with new ideas and solutions", and "willingness to question your own and others' ideas". Female students reported achieving more skills than the male students in "knowledge of other fields or disciplines", and having started from lower level they achieved a higher level than their male counterparts. The female students also made more progress than male students in the following competences: "ability to negotiate effectively", "ability to perform well under pressure", and "ability to write and speak in a foreign language".

This study witnessed significant increase in students' competence by the end of an academic session. This paper concludes that higher education plays positive role in the development of generic competences among students, and that the specific gender differences were noted in 9 out of 19 competences. Role of higher education in developing (generic, specific, and disposition) competences has earlier been discovered by some other researchers (Shah, 2009; Chan et al., 2013); this is what endorses the conclusion of present study. This conclusion comes to appear more vital in the wake of the findings of Baartman and Ruijs (2011), that at the beginning of academic sessions the students usually overestimate their competences, and they tend to underestimate their competences at the end of the academic programme.

\section{Implications}

Teaching generic competence to the students of higher education (Haider, 2008) is explicitly lacking in Pakistan. The debate on teaching explicitly/implicitly the generic competence has not been concluded yet (King, 2011). Being hidden the generic competence (Singh et al., 2012) should be implicit in the curriculum practices. Contrary to this, the generic competence should be explicit in curriculum practices (Maher and Graves, 2007; Pandiyan, 2011; Yorke et al., 2004) because of their active role in the professional successful life. Generic competences guarantees graduates better professional life (Schaeper, 2009; Williams, 2003). Further investigations are severely required in Pakistani context, and therefore, sincerely encouraged. Inviting other courageous researchers, this study contributes to offer evidence to students, teachers, administrators and policy makers at higher education level.

It is observed that during only one academic session the assessment practices greatly improved the level of generic competences (Dainty et 
al., 2004; Fortin and Legault, 2010; Male et al., 2011). If the growth of generic competence is high on the agenda of higher education, then its assessment should also be high. We know that Pakistani higher education is assessment oriented (Ali et al., 2009). Therefore, the assessment of generic competence, if put high in the assessment practices, will help developing it among the graduates.

At the policy level, higher education focuses on generic competence, but it is seriously lacking in practice (at the curriculum and assessment) level (Fallows and Steven, 2000); and this is exactly the case in Pakistan. Present research invites policy makers to consider this newly investigated domain to be included in policy, and be executed in practice.

\section{Recommendations}

We intend to evaluate the contribution of higher education in developing generic competences among students of higher education in Pakistan; for, there is wide agreement that the role of higher education includes preparing young people for employment (Nunan, 1999). As evidenced empirically, that the job market expects higher education students to get developed their specific and generic competences (Pukelis and Pileicikiene, 2009; Shah, 2009), Pakistani higher education institutions would be imperatively required to adapt "competence-based education".

The limitation of this study is that only one university was included in the survey, and results from other universities might be different. This study can be replicated for other universities, thus allowing for a comparative analysis of how generic competences evolve over time, with an additional focus on gender differences.

Higher education institutions are increasingly focussed on the development of generic competences (García-Aracil and Van der Velden, 2008; Teichler, 1999). Pakistani researchers should also come to invest their efforts in researching in this area in order to present genuine solutions to indigenous problems in this context.

\section{Acknowledgment}

The study used generic competence scale developed by the Reflex Team in 2004 in Europe; which was further studied by Shah (2009) in France while working on reliability of graduates' self-assessment; this scale was adopted and validated by Shamim-ur-Rasool (2012) in Pakistan. Hereby, contribution of all the researchers in this regard is acknowledged. 


\section{References}

Ali, A., Tariq, R. H., \& Topping, J. (2009). Students' perception of university teaching behaviours. Teaching in Higher Education, 14(6), 631-647.

Ashworth, P. D., \& Saxton, J. (1990). On competence. Journal of Further and Higher Education, 14(2), 3-25.

Baartman, L., Gulikers, J., \& Dijkstra, A. (2013). Factors influencing assessment quality in higher vocational education. Assessment \& Evaluation in Higher Education, 38 (8), 1-20.

Baartman, L., \& Ruijs, L. (2011). Comparing students' perceived and actual competence in higher vocational education." Assessment \& Evaluation in Higher Education, 36 (4), 385-398.

Bordens, K. S., \& Abbot, B.B. (2006). Research Design \& Methods: A process approach. Tata McGraw-Hill Education: New York.

Chan, R. Y., Brown, G. T., \& Ludlow, L. H. (2013). What is the purpose of higher education?: Comparing student and institutional perspectives for completing a bachelor's degree in the 21 st century.

Clanchy, J., \& Ballard, B. (1995). Generic skills in the context of higher education. Higher Education Research and Development, 14(2), 155-166.

Collis, D. J., \& Montgomery, C. A. (1995). Competing on resources. Harvard business review, 73(4), 118-128.

Dainty, A. R., Cheng, M. I., and Moore, D. R. (2004). A competence-based performance model for construction project managers. Construction Management and Economics, 22(8), 877-886.

Dillman, D. A. (1991). The design and administration of mail surveys. Annual Review of Sociology, 225-249.

Epstein, R. M., \& Hundert, E. M. (2002). Defining and assessing professional competence. The journal of the American Medical Association, 287(2), 226-235. 
Fagarasanu, M., \& Kumar, S. (2002). Measurement instruments and data collection: a consideration of constructs and biases in ergonomics research. International journal of industrial ergonomics, 30(6), 355-369.

Fair, C. C. (2007). The madrassah challenge: militancy and religious education in Pakistan. Washington. D.C: US Institute of Peace Press.

Fallows, S., \& Steven, C. (2000). Building employability skills into the higher education curriculum: a university-wide initiative. Education+ training, 42(2), 75-83.

Fastré, G. M., van der Klink, M. R., Sluijsmans, D., \& van Merriënboer, J. J. (2013). Towards an integrated model for developing sustainable assessment skills. Assessment \& Evaluation in Higher Education, 38(5), 611-630.

Fortin, A., \& Legault, M. (2010). Development of generic competences: Impact of a mixed teaching approach on students' perceptions. Accounting Education: an international journal, 19(1-2), 93-122.

García-Aracil, A., \& Van der Velden, R. (2008). Competences for young European higher education graduates: labor market mismatches and their payoffs. Higher Education, 55(2), 219-239.

Gay, L. R., Mills, G. E., \& Airasian, P. W. (2006). Educational research: Competences for analysis and applications $\left(8^{\text {th }} \mathrm{ed}\right)$. New York: Prentice Hall.

Ghaemi, S. N., Boiman, E. E., \& Goodwin, F. K. (2000). Diagnosing bipolar disorder and the effect of antidepressants: a naturalistic study. J Clin Psychiatry, 61(10).

Gonczi, A. (1994). Competence based assessment in the professions in Australia. Assessment in Education, 1(1), 27-44.

Gonczi, A. (2002). Teaching and learning of the key competences. Presented at Contributions to the second DeSeCo symposium. Geneva: Swiss Federal Statistical Office. 
Haider, S. Z. (2008). Challenges in higher education: special reference to Pakistan and South Asian developing countries. Nonpartisan Education Review, 4(2).

Harvey, L. (2000). New realities: The relationship between higher education and employment. Tertiary Education \& Management, 6(1), 3-17.

Hernández-March, J., Martín del Peso, M., \& Leguey, S. (2009). Graduates' skills and higher education: The employers' perspective. Tertiary Education and Management, 15(1), 1-16.

Hughes, C. (2013). A case study of assessment of graduate learning outcomes at the programme, course and task level. Assessment \& Evaluation in Higher Education, 38(4), 492-506.

Kamphorst, J., Hofman, W., Jansen, E., \& Terlouw, C. (2012). The relationship between perceived competence and earned credits in competence-based higher education. Assessment \& Evaluation in Higher Education, 1-16.

Khalid, S. M., \& Khan, M. F. (2006). Pakistan: The state of education. The Muslim World, 96(2), 305-322.

King, K. (2011). Towards a new global world of skills development? TVET's turn to make its mark." NORRAG News, 46.

Kothari, C. (2004). Research methodology: Methods and techniques: New Delhi: New Age International.

Maher, A., \& Graves, S. (2007) Making students more employable: can higher education deliver. Presented at Euro CHRIE Conference, Leeds, UK.

Male, S., Bush, M., \& Chapman, E. (2011). An Australian study of generic competences required by engineers. European Journal of Engineering Education, 36(2), 151-163.

Mann, H. B., \& Whitney, D. R. (1947). On a test of whether one of two random variables is stochastically larger than the other. The Annals of Mathematical Statistics, 18(1), 50-60. 
Mason, G., Williams, G., \& Cranmer, S. (2009). Employability skills initiatives in higher education: what effects do they have on graduate labour market outcomes? Education Economics, 17(1), 1-30.

McKnight, P. E., \& Najab, J. (2010). Mann Whitney U Test. Corsini Encyclopedia of Psychology.

McNamara, J. (2013). The challenge of assessing professional competence in work integrated learning. Assessment \& Evaluation in Higher Education, 38(2), 183-197.

Memon, G. R. (2007). Education in Pakistan: The key issues, problems and the new challenges. Journal of Management and Social Sciences, 3(1), 47-55.

Norman, I. J., Watson, R., Murrells, T., Calman, L., \& Redfern, S. (2002). The validity and reliability of methods to assess the competence to practise of pre-registration nursing and midwifery students. International Journal of Nursing Studies, 39(2), 133-145.

Nunan, T. (1999). Graduate qualities, employment and mass higher education. Flexible Learning Centre, University of South Australia, Australia http://www. herdsa. org. au/branches/vic/Cornerstones/pdf/ Nunan. PDF.

Pandiyan, A. (2011). Employers' Perspective of MBA Curriculum in Meeting the Requirements of the Industry. Management and Labour Studies, 36(2), 143-154.

Pukelis, K. (2009). Ability, competence, learning/study outcome, qualification and competence: theoretical dimension. Aukštojo mokslo kokybe (06), 12-35.

Pukelis, K., and Pileicikiene, N. (2009). Matching of Generic Competences with Labour Market Needs: Important Factor of Quality of Study Programmes. Development of Competences in the World of Work and Education.

Robson, C. (2002). Real world research: A resource for social scientists and practitioner-researchers. Blackwell Oxford. 
Saunders, M. N., Saunders, M., Lewis, P., \& Thornhill, A. (2011). Research Methods For Business Students, 5/e: Pearson Education India.

Schaeper, H. (2009). Development of competences and teaching-learning arrangements in higher education: Findings from Germany. Studies in Higher Education, 34(6), 677-697.

Shah, A. A. (2009). Apports et limites de l'auto-évaluation des compétences par les diplômés de l'enseignement supérieur, Université de Bourgogne.

Shami, P. A., \& Hussain, K. S. (2006). Development of education in Pakistan: Academy of Educational Planning and Management, Ministry of Education.

Singh, P., Narasuman, S., \& Thambusamy, R. X. (2012). Refining teaching and assessment methods in fulfilling the needs of employment: A Malaysian perspective. Futures, 44(2), 136-147.

Teichler, U. (1999). Higher education policy and the world of work: changing conditions and challenges. Higher Education Policy, 12(4), 285-312.

Van der Vleuten, C., Schuwirth, L., Scheele, F., Driessen, E., \& Hodges, B. (2010). The assessment of professional competence: building blocks for theory development. Best Practice \& Research Clinical Obstetrics \& Gynaecology, 24(6), 703-719.

Van Der Vleuten, C. P. (1996). The assessment of professional competence: developments, research \& practical implications. Advances in Health Sciences Education, 1(1), 41-67.

Wilcox, R. R., \& Keselman, H. (2003). Modern robust data analysis methods: measures of central tendency. Psychological Methods, 8 (3), 254.

Williams, P. E. (2003). Roles \& competences for distance education programmes in higher education institutions. The American Journal of Distance Education, 17(1), 45-57.

Yee, J. L., \& Niemeier, D. (1996). Advantages and disadvantages: Longitudinal vs. repeated cross-section surveys. Project Battelle, 94, 16. 
Yorke, M., Knight, P. T., Moon, J., Layer, G., and Moreland, N. (2004). Learning and Employability, York: Learning and Teaching Support Network.

Citation of this Article:

Shah, A. A., Sarwar, M., \& Shah, S.A. (2017). Assessing generic competence development among higher education students. Pakistan Journal of Education, 34(1), 01-20.

Received on: 12 April, 2016

Revised on: 07 May, 2017

Accepted on: 14 June, 2017 